\title{
Response of Heat-Stressed Commercial Broilers To Dietary Supplementation of Organic Chromium
}

\author{
Sumaiya Afrin ${ }^{1}$, Fowzia Sultana ${ }^{2}$, S. D. Chowdhury ${ }^{2}$ and Bibek Chandra Roy ${ }^{3}$ \\ ${ }^{1}$ Lecturer, Department of Poultry Science, BAU, Mymensingh, Bangladesh \\ ${ }^{2}$ Professor, Department of Poultry Science, BAU, Mymensingh, Bangladesh \\ ${ }^{3}$ PhD fellow, Department of Poultry Science, BAU, Mymensingh, Bangladesh
}

\begin{abstract}
The responses of broilers to organic chromium $(\mathrm{Cr})$ fed under heat stress were investigated. About 256 day old Cobb 500 broilers were divided into four dietary groups and fed iso-caloric and iso-nitrogenous diets containing 0, 0.005, 0.010 and 0.015\% organic Cr (yeast fermented) up to 35 days. Feed intake, body weight gain and feed conversion ratio (FCR) were measured. Blood samples were collected at 22 and 34 days of age to determine serum parameters. On 35 days, 2 broilers from each replicate were slaughtered to determine carcass traits. Body weight and weight gain of broilers fed $\mathrm{Cr}$ were significantly increased at 21 and 35 days $(P<0.01)$. Feed intake was not affected up to 21 days but increased in Cr groups $(P<0.05)$ from 22 to 35 days. The lowest FCR was recorded for $0.010 \% \mathrm{Cr}(P<0.01)$. A significant decrease $(P<0.01)$ in abdominal fat were observed in Cr group. Antibody titer against Newcastle virus was increased $(P<0.01)$ in both 0.005 and $0.010 \% \mathrm{Cr}$ at 22 days. Heterophyl to lymphocyte ratio was decreased $(P<0.01)$ in 0.010 and $0.015 \%$ Cr. It was therefore concluded that $0.010 \%$ dietary organic $C r$ supplementation may be used to improve productive performance and immune status with a reduction in abdominal fat content of broilers under heat stress condition.
\end{abstract}

Keywords: broilers, heat stress, immune response, organic Cr, performance

\section{Introduction}

Heat stress is one of the most important environmental stressors challenging poultry production in tropical countries. It has detrimental effects on feed intake, growth rate, feed efficiency, carcass quality and health of broilers. Scientists reported that chronic heat stress increased mortality and time to reach market weight of broilers [1]. Trivalent Cris used in poultry diet to combat the negative effects of heat stress [2]. It is an essential element in human and animal body [3]. Chromium is a component of glucose tolerance factor (GTF) and is important in carbohydrate, fat, and protein metabolism presumably by potentiating the action of insulin [4]. Supplementation of $\mathrm{Cr}$ has been found to improve feed intake, feed efficiency and body weight of heat stressed broilers [2]. Scientists also observed an increase in carcass yield and a decrease in abdominal fat content in $\mathrm{Cr}$-supplemented diet. Chromium has antioxidant activity which is mediated by suppressing the production of corticosterone, which is a potent immunosuppressant by inhibiting production of antibodies, lymphocyte function and leukocyte population [5] [14]. Therefore, supplementation of $\mathrm{Cr}$ may beneficially influence the immune response in broiler chicken [6].

Research on animals has confirmed that $\mathrm{Cr}$ from organic complexes absorbed more efficiently (about 20-30\%) than inorganic salts (about 1-3\%) [7]. The value of $\mathrm{Cr}$ supplementation is 300 microgram $\mathrm{Cr}$ per $\mathrm{kg}$ diet for laboratory animals [3]. Stress and disease increase urinary excretion of $\mathrm{Cr}$ and may exacerbate a marginal $\mathrm{Cr}$ deficiency. However, an appropriate recommendation on the $\mathrm{Cr}$ requirement of poultry has not yet been made and the research studies carried out over the past decades have not established the optimum dietary concentration of $\mathrm{Cr}$ for poultry, particularly in heat stress. Moreover, for the highlighted awareness of growth and meat quality in the poultry industry and possible supplementation of $\mathrm{Cr}$ in broiler diet during heat stress, the effect of organic $\mathrm{Cr}$ on growth, meat quality and immunity of broilers need to be more clearly defined.The objectives of this study were, therefore, to evaluate the effect of dietary organic $\mathrm{Cr}$ (yeast fermented) on growth performance, carcass traits and some immunological parameters of broilers during heat stress.

\subsection{Broilers and managements}

\section{Materials And Methods}

A total of 256 Cobb 500 commercial one-day old broiler chicks were randomly divided into four dietary treatment groups. Each group was replicated to four sub-groups each consisting of 16 birds. The dietary treatments consisted of a basal diet supplemented with 0 (control), $0.005,0.010$ and $0.015 \%$ organic $\mathrm{Cr}$ (yeast fermented, Chromisac, Zeus Biotech Limited, Mysore-570016 India ) Broilers were given a starter diet from 0 to 21 days and a grower diet from 22 to 35 days. The ingredient composition of starter and grower diets is shown in Table 1. Fresh feed and clean drinking water were supplied ad libitum and both temperature and 
humidity of the experimental shed were recorded four times (6 AM, 2 PM, 6 PM, 11 PM) in a day. During $4^{\text {th }}$ and $5^{\text {th }}$ weeks of age the temperature inside the experimental shed was $33.35 \pm 2.5$ and $32.1 \pm 2.5{ }^{0} \mathrm{C}$, respectively.

Table 1 Ingredient composition of commercial broiler starter and grower diets*

\begin{tabular}{|c|c|c|}
\hline \multirow[t]{2}{*}{ Ingredient } & \multicolumn{2}{|c|}{ Amount (\%) } \\
\hline & Starter & Grower \\
\hline Yellow corn & 51.16 & 61.45 \\
\hline Soybean meal $44 \%$ & 41.71 & 31.63 \\
\hline Soybean oil & 3.38 & 3.1 \\
\hline Limestone & 0.952 & 0.94 \\
\hline DCP(Di-calcium-phosphate) & 1.63 & 1.725 \\
\hline Broiler premix & 0.25 & 0.25 \\
\hline Common salt & 0.273 & 0.273 \\
\hline $\mathrm{NaHCO}_{3}$ & 0.23 & 0.23 \\
\hline L-lysine & 0.08 & 0.11 \\
\hline DL-Methionine & 0.305 & 0.252 \\
\hline L-Threonine & 0.03 & 0.04 \\
\hline Total & 100 & 100 \\
\hline \multicolumn{3}{|l|}{ Nutrient } \\
\hline $\mathrm{ME}(\mathrm{kcal} / \mathrm{kg})$ & 3000 & 3100 \\
\hline Crude Protein $(\%)$ & 24 & 21 \\
\hline Fiber $(\%)$ & 3.61 & 3.61 \\
\hline Threonine $(\%)^{*}$ & 0.8 & 0.8 \\
\hline Methionine (\%) & 0.5 & 0.5 \\
\hline Lysine $(\%)$ & 1.5 & 1.5 \\
\hline Calcium $(\%)$ & 0.91 & 091 \\
\hline Available P (\%) & 0.51 & 0.51 \\
\hline \multirow[t]{2}{*}{ Ingredient } & \multicolumn{2}{|c|}{ Amount (\%) } \\
\hline & Starter & Grower \\
\hline Yellow corn & 51.16 & 61.45 \\
\hline Soybean meal $44 \%$ & 41.71 & 31.63 \\
\hline Soybean oil & 3.38 & 3.1 \\
\hline Limestone & 0.952 & 0.94 \\
\hline DCP(Di-calcium-phosphate) & 1.63 & 1.725 \\
\hline Broiler premix & 0.25 & 0.25 \\
\hline Common salt & 0.273 & 0.273 \\
\hline $\mathrm{NaHCO}_{3}$ & 0.23 & 0.23 \\
\hline L-lysine & 0.08 & 0.11 \\
\hline DL-Methionine & 0.305 & 0.252 \\
\hline L-Threonine & 0.03 & 0.04 \\
\hline Total & 100 & 100 \\
\hline \multicolumn{3}{|l|}{ Nutrient } \\
\hline ME (kcal/kg) & 3000 & 3100 \\
\hline Crude Protein $(\%)$ & 24 & 21 \\
\hline Fiber $(\%)$ & 3.61 & 3.61 \\
\hline Threonine $(\%)^{*}$ & 0.8 & 0.8 \\
\hline Methionine (\%) & 0.5 & 0.5 \\
\hline Lysine (\%) & 1.5 & 1.5 \\
\hline Calcium (\%) & 0.91 & 091 \\
\hline Available P (\%) & 0.51 & 0.51 \\
\hline
\end{tabular}

* Nutrients requirements were close to the standard recommended for Cobb 500 commercial broiler (ref. 2012).Please mention the calculated value of ME, CP and other nutrients obtained from the tabulated amount.

\subsection{Data collection and record keeping}

The day-old chicks were weighed group-wise upon arrival and then every 7 days intervals until 35 days of age. The average live weight, weight gain, feed intake, FCR and survivability of the broilers reared on different dietary treatments were calculated. At the end of the experiment, 32 broilers, one male and one female broiler from each replication were selected, weighed and sacrificed to determine carcass traits.

\subsection{Collection of blood samples for serum parameters}

At 22 and 34 days of age, one broiler from each replication was randomly selectedchosen and blood samples were collected to determine antibody titers against Newcastle Disease virus vaccine (Table 2) by Haemagglutination inhibition (HI) test following the method described by Anon (1971). Blood samples were collected further when the room temperature was more than $35^{\circ} \mathrm{C}$ to determine heterophyl to lymphocyte ratio by following Different Leukocyte Count (DLC) method. 
Table 2 Vaccination schedule

\begin{tabular}{|l|l|l|l|l|}
\hline Age & Name of vaccine & Trade name of vaccine & Method of vaccination & Dose \\
\hline $4^{\text {th }}$ Day & IB+ND & MA $_{5}+$ Clone $30^{*}$ & Eye drop & 1 eye drop/bird \\
\hline $10^{\text {th }}$ Day & (Gumboro) & $228 \mathrm{E}^{*}$ & Eye drop & 1 eye drop $/ \mathrm{bird}$ \\
\hline $17^{\text {th }}$ Day & (Gumboro) & $228 \mathrm{E}^{*}$ & Eye drop & 1 eye drop/bird \\
\hline $21^{\text {st }}$ Day & ND & $228 \mathrm{E}^{*}$ & Eye drop & 1 eye drop/bird \\
\hline
\end{tabular}

\subsection{Statistical analysis}

All recorded and calculated variables were subjected to analysis of variance (ANOVA) in a Completely Randomized Design (CRD) by following a statistical package SAS, 2008 [8]. Duncan's Multiple Range Test (DMRT) was used to compare treatment means.

\section{Results And Discussion}

Performances of broilers fed organic Cr supplemented diets are shown in Table 3. Live weight and live weight gain of broilers receiving $0.010 \% \mathrm{Cr}$ were heavier at both 21 and 35 days of age than other treatments $(\mathrm{P}<0.01)$. Other study observed that $300 \mathrm{ppb} \mathrm{Cr}$ yeast in diet showed highest body weight in broiler at 3 and 6 weeks $(\mathrm{P}<0.05)$ of age [9]. Dietary $\mathrm{Cr}$ supplementation has also been shown to positively affect growth rate and feed efficiency in growing broilers [10] [11]. However, such beneficial effect of organic $\mathrm{Cr}$ on growth contradicted with a work conducted earlier [12]. These authors reported that organic $\mathrm{Cr}$ supplementation at 200 and $400 \mathrm{ppb} \mathrm{Cr}$ did not affect live weight of broilers of 3 weeks of age. In fact $\mathrm{Cr}$ compounds act as (GTF), which increases insulin signaling and promotes glucose metabolism, enhances glycogenesis from glucose and accelerates glucose transport and muscle build up as well as growth rate [13]. It also improves amino acid uptake by tissues and muscle cells and increase protein retention and tend to increase body weight in broilers.

The broilers in control diet had lowest feed intake while broilers in $0.005 \%, 0.010 \%, 0.015 \% \mathrm{Cr}$ supplemented diets had higher feed intake $(\mathrm{P}<0.05)$ during $22-35$ days. Total feed intake per broiler from $0-35$ days of age revealed that supplementation of $\mathrm{Cr}$ in broiler diets resulted in increased feed intake $(\mathrm{P}<0.01)$ during heat stress compared to that of control group. This result agreed well with the findings of other scientists [2] [14]. It was hypothesized that $\mathrm{Cr}$ increased glucose uptake, decreased blood glucose and increased appetite, thereby increasing feed intake. However, such beneficial effect of organic $\mathrm{Cr}$ on feed intake of broiler was contradictory to the results obtained by others who reported unaffected feed intake by broiler fed on diets with Cr supplementation [15] [16] .

(FCR from 0-5 weeks of age decreased significantly $(\mathrm{P}<0.01)$ in $0.010 \% \mathrm{Cr}$ supplemented group compared to that of control and other groups. No significant difference in FCR was observed among other experimental groups from 0-35 days of age. Studies with Cr-yeast showed supplementation of $300 \mathrm{ppb}$ and 500 ppb Cr from Cr yeast improved FCRof heat stressed broilers [9] [17]. However, Another report showed that FCR of broilers receiving organic Cr supplemented diets did not significantly differ from control during heat stress [18]. The improvement in FCR could be due to the fact that yeast derived $\mathrm{Cr}$ is considered to be the most biologically active and observable form of $\mathrm{Cr}$.

Table 3 Performance of broilers fed diets supplemented with different levels of organic chromium $(\mathrm{Cr})(0-35$ days)

\begin{tabular}{|c|c|c|c|c|c|c|}
\hline \multirow[t]{2}{*}{ Parameter } & \multirow{2}{*}{$\begin{array}{l}\text { Age } \\
\text { (day) }\end{array}$} & \multicolumn{4}{|c|}{ Dietary Cr level (\%) } & \multirow{2}{*}{$\begin{array}{l}\text { Level of } \\
\text { signif- } \\
\text { icance }\end{array}$} \\
\hline & & 0.00 & 0.005 & 0.010 & 0.015 & \\
\hline $\begin{array}{l}\text { Initial body } \\
\text { weight } \\
\text { (g/broiler) }\end{array}$ & 1 & $46.63 \pm 0.03$ & $46.71 \pm 0.04$ & $46.84 \pm 0.12$ & $46.69 \pm 0.10$ & NS \\
\hline \multirow{2}{*}{$\begin{array}{l}\text { Live weight } \\
\text { (g/broiler) }\end{array}$} & 21 & $690.63^{b} \pm 15.86$ & $732.19^{\mathrm{a}} \pm 13.30$ & $771.72^{\mathrm{a}} \pm 13.60$ & $764.36^{\mathrm{a}} \pm 9.19$ & $* *$ \\
\hline & 35 & $1685.24^{\mathrm{c}} \pm 16.55$ & $1816.17^{\mathrm{b}} \pm 38.27$ & $1924.92^{\mathrm{a}} \pm 32.84$ & $1832.03^{b} \pm 12.43$ & ** \\
\hline \multirow{3}{*}{$\begin{array}{l}\text { Body weight } \\
\text { gain } \\
\text { (g/broiler) }\end{array}$} & $0-21$ & $644.80^{b} \pm 15.85$ & $685.48^{\mathrm{ab}} \pm 13.27$ & $724.88^{\mathrm{a}} \pm 13.27$ & $717.9^{\mathrm{a}} \pm 9.19$ & $* *$ \\
\hline & $22-35$ & $994.61^{c} \pm 7.33$ & $1083.98^{\mathrm{b}} \pm 29.05$ & $1153.2^{\mathrm{a}} \pm 27.74$ & $1067.67^{\mathrm{b}} \pm 13.56$ & $* *$ \\
\hline & $0-35$ & $1638.61^{\mathrm{c}} \pm 16.54$ & $1769.47^{b} \pm 38.27$ & $1878.09^{\mathrm{a}} \pm 32.85$ & $1785.35^{b} \pm 12.84$ & *** \\
\hline \multirow{3}{*}{$\begin{array}{l}\text { Feed intake } \\
\text { (g/broiler) }\end{array}$} & $0-21$ & $1040.70 \pm 11.44$ & $1083.52 \pm 24.50$ & $1037.81 \pm 23.01$ & $1094.77 \pm 12.69$ & NS \\
\hline & $22-35$ & $1781.75^{\mathrm{b}} \pm 32.34$ & $1890.94^{\mathrm{a}} \pm 8.87$ & $1892.73^{\mathrm{a}} \pm 24.57$ & $1869.77^{\mathrm{a}} \pm 23.51$ & $*$ \\
\hline & $0-35$ & $2843.14^{b} \pm 30.26$ & $2974.47^{\mathrm{a}} \pm 30.48$ & $2930.55^{\mathrm{a}} \pm 6.36$ & $2964.54^{\mathrm{a}} \pm 20.59$ & $* *$ \\
\hline \multirow{3}{*}{$\begin{array}{l}\text { Feed } \\
\text { Conversion } \\
\text { ratio }\end{array}$} & $0-21$ & $1.62^{\mathrm{a}} \pm 0.07$ & $1.58^{\mathrm{a}} \pm 0.03$ & $1.43^{b} \pm 0.05$ & $1.53^{\mathrm{ab}} \pm 0.02$ & $*$ \\
\hline & $22-35$ & $1.79^{\mathrm{a}} \pm 0.04$ & $1.75^{\mathrm{a}} \pm 0.05$ & $1.64^{\mathrm{b}} \pm 0.02$ & $1.75^{\mathrm{a}} \pm 0.05$ & $*$ \\
\hline & $0-35$ & $1.74^{\mathrm{a}} \pm 0.03$ & $1.68^{\mathrm{a}} \pm 0.03$ & $1.56^{\mathrm{b}} \pm 0.022$ & $1.66^{\mathrm{a}} \pm 37.976$ & $* *$ \\
\hline \multirow{3}{*}{$\begin{array}{l}\text { Survivability(\% } \\
\text { ) }\end{array}$} & $0-21$ & $100 \pm 0$ & $100 \pm 0$ & $100 \pm 0$ & $100 \pm 0$ & NS \\
\hline & $22-35$ & $96.88 \pm 1.8$ & $98.44 \pm 1.56$ & $100 \pm 0$ & $98.44 \pm 1.56$ & $\mathrm{NS}$ \\
\hline & $0-35$ & $96.88 \pm 1.8$ & $98.44 \pm 1.56$ & $100 \pm 0$ & $98.44 \pm 1.56$ & NS \\
\hline
\end{tabular}

NS: Non significant; $* *, \mathrm{P}<0.01 ;^{\text {abcd }}$, values in the same row bearing different superscripts are significantly different 
Table 4 Carcass traits at 35 days of age of broilers fed diets supplemented with different levels of organic chromium $(\mathrm{Cr})$

\begin{tabular}{|c|c|c|c|c|c|}
\hline \multirow{2}{*}{$\begin{array}{l}\text { Parameter } \\
(\%)\end{array}$} & \multicolumn{4}{|c|}{ Dietary Cr level } & \multirow{2}{*}{$\begin{array}{l}\text { Level of } \\
\text { signifi- } \\
\text { cance }\end{array}$} \\
\hline & $0.00 \%$ & $0.005 \%$ & $0.01 \% \mathrm{Cr}$ & $0.015 \% \mathrm{Cr}$ & \\
\hline Live Wt(g/broiler) & $1723 \pm 76.80$ & $1910.5 \pm 47.65$ & $1972.5 \pm 11.99$ & $1838.25 \pm 125.17$ & NS \\
\hline $\begin{array}{l}\text { Dressing percent } \\
\text { (without skin) }\end{array}$ & $64.79 \pm 1.89$ & $67.13 \pm 0.32$ & $67.61 \pm 1.64$ & $64.99 \pm 1.12$ & NS \\
\hline Thigh wt & $15.98 \pm 0.75$ & $15.94 \pm 0.73$ & $13.73 \pm 0.20$ & $14.91 \pm 0.79$ & NS \\
\hline Drumstick wt & $9.8 \pm 0.36$ & $9.64 \pm 0.36$ & $9.61 \pm 0.17$ & $9.59 \pm 0.12$ & NS \\
\hline Breast meat wt & $38.51 \pm 2.05$ & $42.89 \pm 1.31$ & $41.57 \pm 2.24$ & $38.62 \pm 1.05$ & NS \\
\hline Wing wt & $8.69^{b} \pm 0.26$ & $8.45^{\mathrm{b}} \pm 0.12$ & $9.84^{\mathrm{a}} \pm 0.11$ & $9.15^{\mathrm{ab}} \pm 0.46$ & $*$ \\
\hline Head wt & $1.97 \pm 0.18$ & $1.97 \pm 0.11$ & $2.16 \pm 0.07$ & $2.28 \pm 0.15$ & NS \\
\hline Neck wt & $8.24^{\mathrm{a}} \pm 0.27$ & $7.87^{\mathrm{ab}} \pm 0.22$ & $9.08^{\mathrm{a}} \pm 0.42$ & $6.74^{\mathrm{b}} \pm 0.62$ & $*$ \\
\hline Liver wt & $2.99^{\mathrm{b}} \pm 0.09$ & $4.43^{\mathrm{a}} \pm 0.46$ & $5.45^{\mathrm{a}} \pm 0.63$ & $5.05^{\mathrm{a}} \pm 0.25$ & $* *$ \\
\hline Gizzard wt & $3.58 \pm 0.18$ & $2.8 \pm 0.69$ & $3.47 \pm 0.18$ & $3.19 \pm 0.12$ & NS \\
\hline Heart wt & $0.96 \pm 0.05$ & $1.00 \pm 0.15$ & $1.12 \pm 0.13$ & $0.99 \pm 0.11$ & NS \\
\hline Abdominl fat wt & $4.51^{\mathrm{a}} \pm 0.44$ & $1.42^{\mathrm{b}} \pm 0.23$ & $1.3^{\mathrm{b}} \pm 0.11$ & $1.3^{\mathrm{b}} \pm 0.14$ & $* *$ \\
\hline
\end{tabular}

NS: Non significant; *, $\mathrm{P}<0.05 ; * *, \mathrm{P}<0.01 ;^{\text {abcd }}$, values in the same row bearing different superscripts are significantly different

Supplementation of organic $\mathrm{Cr}$ had no significant effect on survivability of broilers $(\mathrm{P}<0.05)$. The result corresponds well with the recent findings [18] [19]. On the otherhand a significant increase in survivability was reported with $400 \mathrm{ppb}$ and $300 \mathrm{ppb} \mathrm{Cr}$ from $\mathrm{Cr}$ yeast $(\mathrm{P}<0.05)$ [9]. Cr reduces the secretion of corticosterore (which is responsible for increasing stress and reducing immunity and ultimately increasing mortality) and increases immune responses which may be beneficial for increasing survivability of heat stressed broilers.Effects of supplementation of organic $\mathrm{Cr}$ on the carcass traits of broilers at 35 days are shown in Table 4. Wing weight was higher in $0.010 \% \mathrm{Cr}$ diet and neck weight was higher in control and $0.010 \% \mathrm{Cr}$ diet than other experimental diets $(\mathrm{P}<0.05)$. Liver weight was increased significantly in $\mathrm{Cr}$ supplemented group than the birds reared on control diet $(\mathrm{P}<0.01)$. There was a clean indication of reduced abdominal fat content in the $\mathrm{Cr}$ supplemented groups $(\mathrm{P}<0.01)$. Decreasing abdominal fat content in broilers has been reported for diets supplemented with Cr-yeast [9] [20]. On the contrary, another report showed that abdominal fat content of broilers was not affected by supplementation of organic $\mathrm{Cr}$ in diets [19] [21]. At 22 days, $0.005 \%$ and $0.010 \%$ of organic $\mathrm{Cr}$ significantly increased antibody titers against Newcastle Disease virus compared with the control treatment $(\mathrm{P}<0.01)$. But no significant difference was observed for antibody titers against Newcastle Disease virus among the groups at 34 days of age. It was reported that antibody titers against Newcastle virus increased in broilers fed 2 or $10 \mathrm{ppm}$ of $\mathrm{Cr}$ in the form of $\mathrm{Cr}$ yeast in heat-stress conditions [22]. Decreased heterophyl-tolymphocyte ratios in broilers receiving the organic $\mathrm{Cr}$ supplements $(0.010$ and $0.015 \%)$ compared with control was found at 35days and this result was in agreement with [23]. They observed increased lymphocyte count and consequently decreased H: L ratios in the 800 or 1,200 ppb of organic Cr groups. Organic Cr supplementation in heat stress may be attributed to a decreased secretion of glucocorticoid, which results in an increase in lymphocyte counts and decrease in $\mathrm{H}$ : $\mathrm{L}$ ratios.

Table 5 Effect of dietary organic chromium $(\mathrm{Cr})$ on antibody titer and Heterophyl: Lymphocyte (H:L ratio)

\begin{tabular}{|c|c|c|c|c|c|}
\hline \multirow[t]{2}{*}{ Variable } & \multicolumn{4}{|c|}{ Dietary $\mathrm{Cr}$ level } & \multirow{2}{*}{$\begin{array}{l}\text { Level of signifi- } \\
\text { cance }\end{array}$} \\
\hline & $0.00 \%$ & $0.005 \%$ & $(0.010 \%)$ & $0.015 \%$ & \\
\hline HI titer (22 day) & $40^{5} \pm 22.34$ & $102.4^{2 b}=38.4$ & $179.2^{2} \pm 31.35$ & $35.2^{b}=11.76$ & ** \\
\hline HI titer (34 day) & $163.7 \pm 26.51$ & $193.13 \pm 32.15$ & $209.44 \pm 35.53$ & $192.63 \pm 42.6$ & NS \\
\hline H:L (34 day) & $0.62^{2}=0.044$ & $0.59 \div 0.048$ & $0.28^{2} \pm 0.035$ & $0.26^{5} \pm 0.034$ & ** \\
\hline
\end{tabular}

NS: Non significant; **, $\mathrm{P}<0.01 ;^{\text {abcd }}$, values in the same row bearing different superscripts are significantly different

Total production costs were lower in Cr supplemented diet compared to that of control. Thus the profits per kg broiler were higher in $\mathrm{Cr}$ supplemented diet (Tk.12.78, 20.22 and 15.29 for $0.005,0.010$ and $0.015 \% \mathrm{Cr}$ diets, respectively) than the control (Tk. 6.15) and it was highest in $0.010 \%$ Cr supplemented diet (Tk. 20.22).

\section{Conclusion}

Organic $\mathrm{Cr}$ (yeast fermented) may be supplemented as a potential feed additive successfully in broiler diets at $0.010 \%$ level for increasing growth, improving immune response and decreasing abdominal fat of broilers. In future both organic and inorganic sources of $\mathrm{Cr}$ and their comparison can be studied as a feed additive in broiler. Also the carcass or meat analysis should be done to find out the residual effect of these $\mathrm{Cr}$ sources in poultry meat. 


\section{References}

[1] Arjona AA, Denbow DM, Weaver WD JR (1988). Effect of heat stress early in life on mortality of broilers exposed to high environmental temperature just prior to marketing. Journal of Poultry Science, 67: 226-236.

[2] Sahin K, Sahin N, Onderc IM, Gursu F, Cikim G (2002). Optimal dietary concentration of chromium for alleviating the effect of heat stress on growth, carcass qualities and some serum metabolites of broiler chickens. Journal of Biological Trace Element Research, 89:53-64

[3] NRC (1997). Recommended dietary allowances. Nutrient Requirements of Poultry, $9^{\text {th }}$ Revised Edn., National Academy Press, Washington, D.C.

[4] Mertz W (1993). Chromium in human nutrition: a review. Journal of Nutrition, 123: 626-633.

[5] Roth JA, Kaeberle ML (1982). The effect of glucocorticoids on the bovine immune system. Journal of American Veterinary Medicine Association, 180:230-235.

[6] Lee DN, Wu FY, Cheng YH, Lin RS, Wu PC (2003). Effects of dietary chromium picolinate supplementation on growth performance and immune responses of broilers. Asian Australasian Journal of Animal Science, 16: 227-233.

[7] Piva A, Meola E, Gatta PP, Biagi GC, Mordenti AL, Luchansky JB, Silva S Mordenti A (2003). The effect of dietary supplementation with trivalent chromium on production performance of laying hens and the chromium content in the yolk. Animal Feed Science and Technology, 106:149-163

[8] SAS (2008). SAS User's Guide, Version 8 Edition, Cary, NC, USA: Statistical Analysis System Institute. Inc.

[9] Hossain SM, Barreto SL, Silva CG (1998). Growth performance and carcass composition of broilers fed supplemental chromium from chromium yeast. Journal of Animal Feed Science and Technology, 71: 217-228.

[10] Jackson AR, Powell S, Johnston S, Shelton JL, Bidner TD, Valdez FR, Southern LL (2008). The effect of chromium propionate on growth performance and carcass traits in broilers. Journal of Applied Poultry Research, 17: 476-481.

[11] Samanta S, Haldar S, Bahadur V, Ghosh TK (2008). Chromium picolinate can ameliorate the negative effects of heat stress and enhance performance, carcass and meat traits in broiler chickens by reducing the circulatory cortisol level. Journal of the Science and Food Agriculture, 88: 787-796.

[12] Ward TL, Southern LL, Boleman SL (1993). Effect of dietary chromium picolinate on growth, nitrogen balance and body composition of growing broiler chicks. Journal of Poultry Science, 72 (1): 37.

[13] Walker M (1993). Chromium: The essential mineral. Health of Foods Business, 5: 51 - 52.

[14] Toghyani M, Shivazad M, Gheisari AA, Zarkesh SH (2006). Performance, carcass traits and hematological parameters of heat stressed broiler chicks in response to dietary levels of chromium picolinate. International Journal of Poultry Science, 5(1): 65-69.

[15] Habibian M, Gazi S, Moeini MM (2013). Lack of effect of dietary chromium supplementation on growth performance and serum insulin, glucose and lipoprotein levels in broilers reared under heat stress condition. Journal of Biological Trace Element Research, 153(1-3): 205-11.

[16] Farhoomand P, Noori K, Ebrahzadehim SK (2011). Effects of chromium methionine supplements on the performance and serum metabolites of broiler chickens. Journal of Food, Agriculture \& Environment, 9(2): 292-294.

[17] Kroliczewaska B, Zawadzki W, Dobrzanski Z, Kaczmarek-Oliwaa (2004). Change in selected serum parameter of broiler chicken fed supplemental chromium. Journal of Animal Physiology and Nutrition, 88: 393-400.

[18] Moeini MM, Bahrami A, Ghazi S, Targhibi MR (2011). The effect of different levels of organic and inorganic chromium supplementation on production performance, carcass traits and some blood parameters of broiler chicken under heat stress condition. Journal of Biological Trace Element Research, 144: 715-724.

[19] Ebrahimnazhad Y, Ghanbari S, Eshratkhah B, Nazeradl K (2012). Effect of dietary chromium supplementation on performance and carcass traits of broiler chicks. Pakistan Journal of Nutrition, 11 (5): 467-472.

[20] Debski B, Zalewski W, Gralak MA and Kosla, T (2004). Chromium yeast supplementation of broilers in an industrial farming system. Journal of Trace Elements in Medicine and Biology, 18: 47-51.

[21] Rao SV, Raju MV, Panda AK, Poonam NS, Murthy OK, Sunder GS (2012). Effect of dietary supplementation of organic chromium on performance, carcass traits, oxidative parameters, and immune responses in commercial broiler chickens. Journal of Biological Trace Element Research, 147 (1-3): 135-41.

[22] Guo YL, Luo XG, Hao ZL, Liu B, Chen JL, Gao FS Yu SX (1999). Effect of chromium on growth performance, serum biochemical traits, immune function and carcass quality of broiler chickens. Journal of Agricultural Science, 32: 79-86.

[23] Bahrami A, Moeini MM, Ghazi SH, Targhibi MR (2012). The effect of different levels of organic and inorganic chromium supplementation on immune function of broiler chicken under heat-stress conditions. Journal of Applied Poultry Research, 21: 209215 . 